\title{
Haemolytic anaemia and acute kidney injury: think beyond the obvious
}

\author{
Jasmine Sethi, ${ }^{1}$ Smita Divyaveer, ${ }^{1}$ Ritambhra Nada, ${ }^{2}$ Harbir Singh Kohli ${ }^{1}$
}

${ }^{1}$ Nephrology, Post Graduate Institute of Medical Education and Research, Chandigarh, India ${ }^{2}$ Histopathology, Post Graduate Institute of Medical Education and Research, Chandigarh, India

\section{Correspondence to Dr Smita Divyaveer: divyaveer.ss@gmail.com}

Accepted 25 July 2020

\section{Check for updates}

(c) BMJ Publishing Group Limited 2020. No commercial re-use. See rights and permissions. Published by BMJ.

To cite: Sethi J, Divyaveer $\mathrm{S}$, Nada $R$, et al. BMJ Case Rep 2020;13:e237434. doi:10.1136/bcr-2020237434

\section{DESCRIPTION}

A 34-year-old woman was admitted with symptoms of easy fatiguability, decreased urine output and jaundice for 1 week. She had similar history of weakness and jaundice 3 months ago that lasted for a week for which she consumed herbal medicines. Laboratory evaluation revealed anaemia with haemoglobin $30 \mathrm{~g} / \mathrm{L}$ that was normocytic normochromic without any fragmented red cells, total leucocyte count $6.7 \times 10^{9} / \mathrm{L}$, platelet count $70 \times 10^{9} / \mathrm{L}$, serum creatinine $9 \mathrm{mg} / \mathrm{dL}$, serum bilirubin of $1.3 \mathrm{mg} / \mathrm{dL}$ (unconjugated $0.7 \mathrm{mg} / \mathrm{dL}$ ), lactate dehydrogenase $700 \mathrm{IU} / \mathrm{L}$, plasma haemoglobin $60 \mathrm{~g} / \mathrm{L}$. Vitamin B12 and folate levels were normal. ANA was 1+homogeneous with normal complements and negative DsDNA. Urine dipstick showed 1 +protein with $2+$ positive for blood and microscopy was normal. Direct Coombs test (DCT) was negative. Ultrasonography abdomen showed mild hepatosplenomegaly. After 2-3 sessions of haemodialysis and blood transfusion a renal biopsy was performed on day 5 of admission. Biopsy showed tubular damage with deposition of brown pigment in tubular epithelium that gave a blue colour on Perl's stain suggesting haemosiderin (figure 1A,B). There was no significant interstital fibrosis and glomeruli were normal. Immunofluorescence was negative for immunoglobulins and complements. Flow cytometry done on peripheral blood granulocytes showed a paroxysmal nocturnal haemoglobinuria $(\mathrm{PNH})$ clone deficient in CD59 suggestive of PNH. Patient was managed with dialysis, diuretics and folate supplementation with advice for bone marrow transplant in future. Her serum creatinine at discharge was $1.1 \mathrm{mg} / \mathrm{dL}$ with haemoglobin of $70 \mathrm{~g} / \mathrm{L}$.

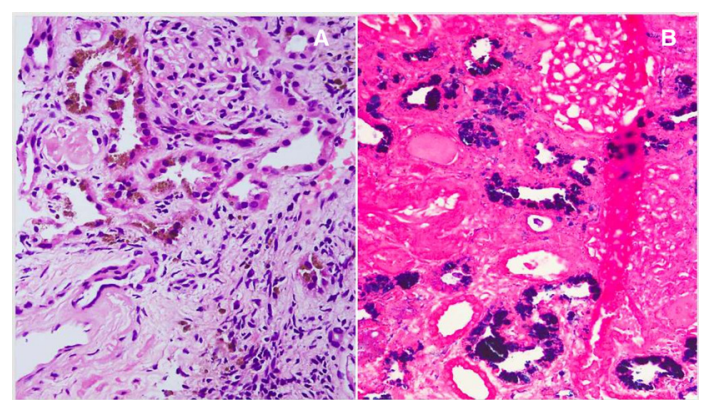

Figure 1 (A) H\&E stain of kidney biopsy showing dilated tubules with flattened epithelium and goldenbrown haemosiderin pigment in tubular epithelium (40x). (B) Perl's Prussian blue stain showing strong positivity for haemosiderin in tubules $(40 \mathrm{x})$.

\section{Learning points}

- One should suspect haemoglobinuria in the presence of dip stick urine positivity for heme and negative urine red blood cell on microscopy.

- One should have a high index of suspicion and evaluate for paroxysmal nocturnal haemoglobinuria in a patient with haemolytic anaemia and acute kidney injury.

Lupus and thrombotic microangiopathy are often considered in the differentials of a patient with renal failure, haemolysis and thrombocytopenia. However, $\mathrm{PNH}$ is also a rare cause that should be suspected in a patient with DCT negative intravascular haemolytic anaemia and after ruling out microangiopathy. PNH can lead to massive haemoglobinuria leading to pigment nephropathy and acute tubular necrosis as in our case and in long term can lead to chronic kidney disease due to haemosiderosis and interstitial scarring. ${ }^{1}$ Intravascular haemolysis can lead to acute kidney injury via multiple mechanisms including formation of intratubular casts and indirect proinflammatory effects via the activation of neutrophils and monocytes. ${ }^{2}$ Allogenic stem cell transplant is the only curative treatment; however, eculizumab has also shown benefit to improve renal function and retard haemolysis in $\mathrm{PNH}^{1}$ The classic triad of haemolysis, thrombosis and thrombocytopenia with cola coloured urine may not be present in each case of $\mathrm{PNH}$ and it requires a high index of suspicion to diagnose it in early stage.

Contributors JS, SD: case identification, writing and research. RN: image acquisition and writing. HSK: final proof reading.

Funding The authors have not declared a specific grant for this research from any funding agency in the public, commercial or not-for-profit sectors.

Competing interests None declared.

Patient consent for publication Obtained.

Provenance and peer review Not commissioned; externally peer reviewed.

\section{REFERENCES}

1 Kokoris SI, Gavriilaki E, Miari A, et al. Renal involvement in paroxysmal nocturnal hemoglobinuria: an update on clinical features, pathophysiology and treatment. Hematology 2018;23:558-66.

2 Van Avondt K, Nur E, Zeerleder S. Mechanisms of haemolysis-induced kidney injury. Nat Rev Nephrol 2019;15:671-92. 
Copyright 2020 BMJ Publishing Group. All rights reserved. For permission to reuse any of this content visit https://www.bmj.com/company/products-services/rights-and-licensing/permissions/

BMJ Case Report Fellows may re-use this article for personal use and teaching without any further permission.

Become a Fellow of BMJ Case Reports today and you can:

- Submit as many cases as you like

Enjoy fast sympathetic peer review and rapid publication of accepted articles

Access all the published articles

Re-use any of the published material for personal use and teaching without further permission

Customer Service

If you have any further queries about your subscription, please contact our customer services team on +44 (0) 2071111105 or via email at support@bmj.com.

Visit casereports.bmj.com for more articles like this and to become a Fellow 